Dokuz Eylül Üniversitesi-Mühendislik Fakültesi Fen ve Mühendislik Dergisi

Cilt 20, Sayı 59, Mayıs, 2018
Dokuz Eylul University-Faculty of Engineering Journal of Science and Engineering Volume 20, Issue 59, May, 2018

DOI: $10.21205 /$ deufmd. 2018205938

\title{
Ağır Taşıtlar İçin Çok Katlı Konvansiyonel Yaprak Yay Yerine Tek Katlı Parabolik Yaprak Yay Tasarımı ve Analizi
}

\author{
Onur KELEBEK ${ }^{1}$, Nusret Sefa KURALAY ${ }^{2}$, Mustafa Umut KARAOĞLAN³
}

${ }^{1}$ Dokuz Eylül Üniversitesi, Fen Bilimleri Enstitüsü, 35397, İzmir (ORCID: http://orcid.org/0000-0003-4766-9468)

${ }^{2}$ Dokuz Eylül Üniversitesi, Mühendislik Fakültesi, Makina Mühendisliği Bölümü, 35397, İzmir (ORCID: http://orcid.org/0000-0002-9609-8289)

${ }^{3}$ Dokuz Eylül Üniversitesi, Mühendislik Fakültesi, Makina Mühendisliği Bölümü, 35397, İzmir (ORCID : http://orcid.org/0000-0002-3780-3451)

(Alınıș / Received: 03.08.2017, Kabul / Accepted: 28.09.2017, Online Yayınlanma/ Published Online: 15.05.2018)

Anahtar Kelimeler Özet: Gelişen teknoloji ile birlikte hafif ve ağır ticari araç Ağır Taşıt, Konvansiyonel Yaprak Yay, Parabolik Yaprak Yay, Sabit Aks üreticileri, şasi altındaki birçok alt parçada ağırlık azaltma çalıșmasını ilke edinmișlerdir. Aracın tekerlek askı sisteminde yer alan yaprak yayların konvansiyonel tipi olanlarında, birim parça ağırlığının parabolik yaprak yaylara göre fazla olması sebebi ile son dönemlerde parabolik yaprak yay üretimi artmış bulunmaktadır. Bu çalışmada, ağır ticari bir aracın ön aksı için tasarlanmış olan mevcut üç katlı konvansiyonel yaprak yay yerine tek katlı parabolik yaprak yayın geometrik tasarımı, katı model olarak hazırlanması, yaprak yay katılığının bilgisayar destekli hesaplanması, belirlenen yaprak yay düșey ve frenleme kuvvetleri girdileri ile gerilme analizinin ve Wöhler eğrisi yardımı ile yorulma analizinin bilgisayar destekli hesaplanması incelenmiștir. Sonuçlar değerlendirilmiştir. Tek katlı parabolik yaprak yay gerilme ve yorulma sonuçları açısından uygun bir tasarımdır.

\section{Design and Analysis of Mono-Leaf Spring Instead of Multi-Leaves Conventional Leaf Spring for Heavy Vehicles}

\begin{tabular}{l}
\hline Keywords \\
Heavy Vehicle, \\
Conventional Leaf \\
Spring, \\
Parabolic Leaf \\
Spring, \\
Rigid Axle
\end{tabular}

Rigid Axle

\begin{abstract}
With the developing technology, light and heavy commercial vehicle manufacturers have adopted the principle of weight reduction studies on many sub-components which assembled under the chassis. The parabolic leaf spring production has been increased in recent years due to the fact that the unit weight of the conventional type of leaf springs in the wheel suspension system of the vehicle is larger than that of the parabolic leaf springs. In this study, current three-layered conventional leaf spring designed for the front axle of a heavy commercial vehicle was replaced by a single-layered parabolic leaf spring that its geometric design as solid model, calculation of rate with computer aided, calculation of stress analysis and
\end{abstract}


fatigue analysis by Wöhler curve with computer aided by specified vertical and brake load inputs were investigated. Results were evaluated. Monoleaf parabolic leaf spring is an appropriate design in terms of results of stress and fatigue.

\section{Giriş}

Araçtaki süspansiyon sistemi, şasi ile yol arasında oluşan tüm kuvvetleri aktarmak için, süspansiyon kolları, yaprak yaylar ve amortisörlerden oluşmaktadır. Yaprak yaylar, aracın şasi ağırlığını taşır ve şasiyi yol bozukluklarından kaynaklı anlık yüksek kuvvetlere karşı korur ve bu durum da aracın sürüş konforuna katkıda bulunur [3]. Yaprak yaya sahip süspansiyon sistemleri, sürüş durumunda lastiklerle beraber çalışması sebebi ile yolcuları veya taşınan yükü muhafaza etmenin yanı sıra sürüș konforunu iyileştirmek amacı ile yoldan gelebilecek titreşim hareketlerini, salınım hareketlerini ve ani kuvvet girdilerini sönümlemek suretiyle yumuşatır. Buna ek olarak şasiyi de korumakla görevlidir. Zemin ile tekerlekler arasındaki sürtünme durumu sonucunda meydana gelen düşey kuvvetler ve fren kuvvetleri yaprak yaylar aracılığı ile şasiye aktarılır [20].

Yaprak yayların, birçok yay katlarının üst üste konması ile oluşması söz konusudur. Farklı tonaj akslarda kullanılması itibari ile tek katlı yaprak yaylar da mevcuttur. Boy olarak en uzun katın ön uç kısımlarının kıvrılması ile meydana gelen göz şeklindeki bölgeden yaprak yay, cıvatası ile askısına monte edilmektedir. Cıvatanın monte edilebilmesi için gözün iç bölgesine kauçuk malzemeden imal edilmiş burç parçaları takılmaktadır. $\mathrm{Bu}$ durum, metalin metalle temasını engellemektedir. Bu burçlar, kullanılan malzeme ve sertlik değerleri itibari ile oluşan kuvvet ve titreşim değerlerini bağlantı bölgelerinde üzerlerine almakta ve kendi içlerinde yok ederek ilgili kuvvet ve titreşimlerin şasiye iletilmesine engel olmaktadırlar. Aynı zamanda, yay üzerine gelen kuvvet sebebi ile eğilmeye çalışırken yay gözünün ileri geri bükülmesine müsaade etmektedirler. Aynı katın arka ucu da tıpkı ön uç gibi kıvrılarak göz formuna getirilir, göz içerisine burç takılır ve yay küpesi aracılığı ile araç şasisine monte edilir. Yay küpesi, yayın eğilme hareketini yapması esnasında yay boyunun uzayıp kisalmasına olanak sağlamaktadır [19].

Konvansiyonel yaprak yaylar, yaprak yaya sahip süspansiyon sistemlerinin en eski olanlarından birisidir. Yaprak yay çeliklerinin farklı boylarda kesilmesi ve üst üste konarak bir merkez cıvatası ile monte edilmesi sonucunda meydana gelirler. Ana kattan diğer katlara doğru gidildikçe katların boylarında kısalma gerçekleşmektedir. Taşınması beklenen yük miktarı arttıkça, kat sayısında da bir artış söz konusudur. Şekil 1'deki çok tabakalı konvansiyonel yaprak yayda, merkez cıvata (1), kelepçe (2), yaprak katları (3), göz sarması (4), göz çapı (5) ve burç (6) numara ile gösterilmiştir.

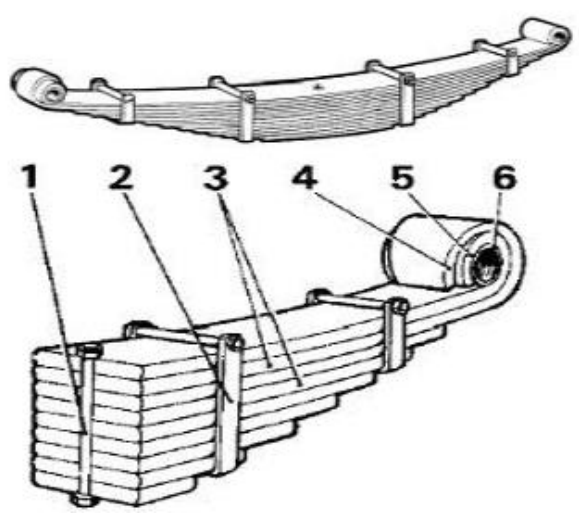

Şekil 1. Konvansiyonel yaprak yay

Parabolik yaprak yay, ismini katların formundan almaktadır. $\mathrm{Bu}$ parabolik form, yaprak yayın uzunluğu boyunca 
sabit eğilme gerilmesi elde edilmesi için verilen en uygun malzeme kullanımı gerekliliğinden dolayı oluşmuştur. Yaprak yay göz kalınlığının, parabolik kol boyunca olan kalınlıktan bağımsız olarak üretilebilir olması yaprak yay için olumlu bir durumdur. Parabolik yaprak yaylar, konvansiyonel yaprak yaylara nazaran yorulma ömrünün uzunluğu, ağırlığının azlığı, tek tabakalı olduğundan tabakalar arası sürtünmenin olmaması ve korozyon direncinin yüksekliği açısından avantajlıdır.

Bu çalışmada, bir ağır taşıt aksı üzerinde yer alan konvansiyonel yaprak yay yerine mevcut aks geometrisinde herhangi bir değişiklik yapılmaksızın tek katlı parabolik yaprak yayın kullanımı hedeflenmiştir. Tasarlanan tek katlı parabolik yayın üretilmesi ile birlikte araç altındaki toplam ağırlığın hafifletilmesi ve yaprak yaydaki ömür artışının elde edilmesi amaçlanmış olup, yapılan yapısal analiz ve hasar analizleri ile bu amaca ulaşıldığı görülmüştür.

\section{Materyal ve Metot}

Yaprak yaylar şasi altında bağlı olduğu diğer parçalar ile hareketli bir mekanizma oluşturması sebebi ile yaprak yayın geometrisi belirlenirken şasi bağlantı noktaları referans alınmaktadır. Şasideki sabit ve hareketli küpeye bağlanan göz bölgelerinin merkezleri arasındaki mesafe, yaprak yayın tam boy eksen ölçüsü olarak adlandırılır. Yaprak yayın tam merkez ekseninden ön gözün merkezine olan mesafe ise ön kol boyu olarak adlandırılır. Bir yaprak yayın eksen boylarını tasarlarken dikkate alınacak eksenler tam boy ve ön kol boyudur. Aks geometrisi dikkate alındığında aracın tam yüklü durumunda ön kol boyu 925 $\mathrm{mm}$, tam boy değeri ise $1850 \mathrm{~mm}$ dir.

Yaprak yayda mekanik özelliklerin istenilen aralıkta sağlanabilmesi için malzemenin doğru seçilmesi son derece önemlidir. En yaygın olarak bilinen yay çelikleri $51 \mathrm{CrV} 4,52 \mathrm{CrMoV} 4$ ve $55 \mathrm{Cr} 3$ olarak belirtilebilir. Yaprak yay malzemesi ısıl işleme tabi tutularak mekanik özellikleri iyileştirilebilen bir yapıya sahiptir. İlgili ham malzeme standardında (DIN EN 10089) belirtilen mekanik özelliklerin, yaprak yay gibi dinamik kuvvetlere maruz kalabilen bir parçada yetersiz kalabilmesi sebebi ile ısıl işlem uygulanması gerekmektedir. Ani su verme ve temperleme operasyonları sonrasında yaprak yayın sertlik değeri ve çekme gerilme değerleri artarak mikro yapı olarak da temperlenmiş martenzitik bir yapı oluşur. Yapılan bu işlemde ilk olarak yaprak yay $900-1000^{\circ} \mathrm{C}$ sıcaklıklarına kadar tavlanarak, mikro yapı östenitik hale getirilir. Daha sonra yağ veya su gibi bir soğutucuya yaprak yayın kendisi daldırılmak suretiyle ani su verme işlemi gerçekleştirilir ve bu safhada içyapı martenzitik bir hal alır. Martenzitik yapı gevrek olduğundan daha tok bir malzeme elde etmek için temperleme işlemi gerçekleştirilir. Tek katlı yaprak yayın kalın bir yaprak yay olması ve sertleşebilme özelliğinin sağlanabilmesi amacıyla içerisinde Molibden elementi olan 52CrMoV4 malzemesi seçilmiştir. Üretilen yayda çekme gerilme değeri için 1600-1700 MPa aralığında olup, sertlik değeri açısından çekme gerilme değerine karşılık gelen aralık ise 467-493 HB şeklindedir.

Bir yaprak yay tasarımında yaprak yay katılığı ve yaya gelen kuvvete bağlı olarak, ön ve arka kollarda gerilme dağılımının optimum olması için en önemli tasarım parametresi parabolik yayın kalınlığıdır. Yaprak yayın haddeleme operasyonu öncesinde, yay göbek düzlügü bölgesi sabit bir kalınlık değerindedir. Haddeleme operasyonu sonrasında göbek düzlügünün başlangıç ve bitiş noktalarından kalınlık düşüşü başlar. Ön ve arka kol boyunca kalınlık değişimi devam etmektedir. Yaprak yayın 
göz bölgesinden kırılmaması için göz bölgesine yakın bir noktada kalınlık değişimi sona erer. Tek katlı parabolik yaprak yayın kesit kalınlığı, çalıșma sınır şartlarına bağlı olarak yayın maruz kalacağı kuvvetler doğrultusunda yapacağı sehim değerlerine bağlı olarak hesaplanmaktadır. İstenen yay katılığ için tasarım aralığı Şekil 2'deki kuvvetsehim grafiği üzerinde gösterilmiştir.

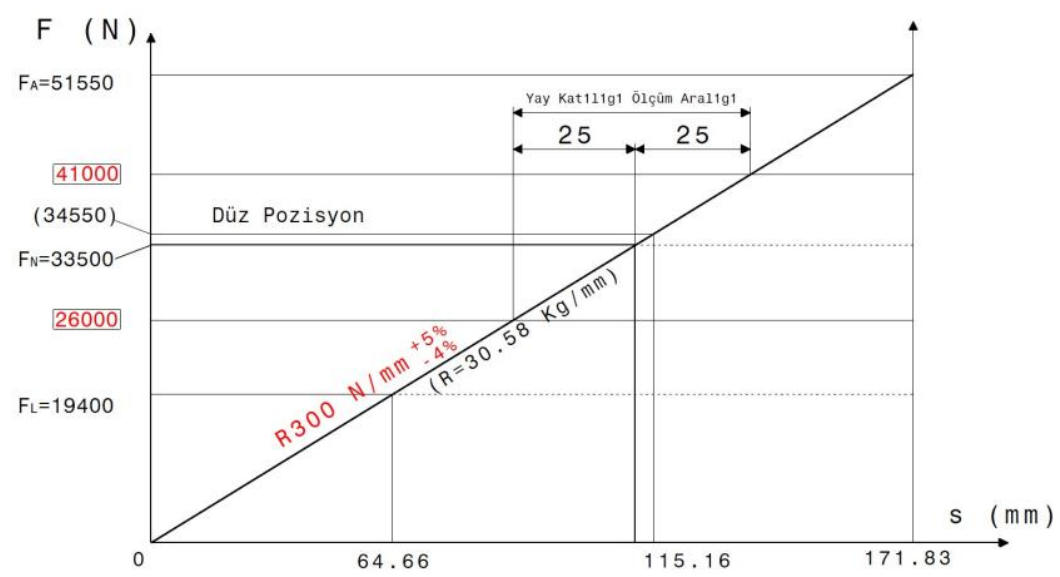

Şekil 2. Tek katlı yaprak yayın kuvvet-sehim grafiği

Yayın taşıdı̆̆ı kuvvet değerinin sehim miktarına olan oranı olarak da bilinen yay katılı̆̆ı, tek katlı bu tasarım için 300 $\mathrm{N} / \mathrm{mm}$ olarak belirlenmiştir. Söz konusu tek katlı yaprak yayın, minimum yay katılığı $288 \mathrm{~N} / \mathrm{mm}$ ve maksimum yay katılığı değeri olarak da $315 \mathrm{~N} / \mathrm{mm}$ olmaktadır. Aks üzerine monte edilen tek katlı yaprak yayın göbek düzlügüundeki genişlik değerinin sabit olması sebebi ile merkezde 5 farklı kalınlık değeri dikkate alınarak yapılan hesaplama sonucunda oluşan yay katılığı sonuçları Şekil 3'te gösterilmiştir.

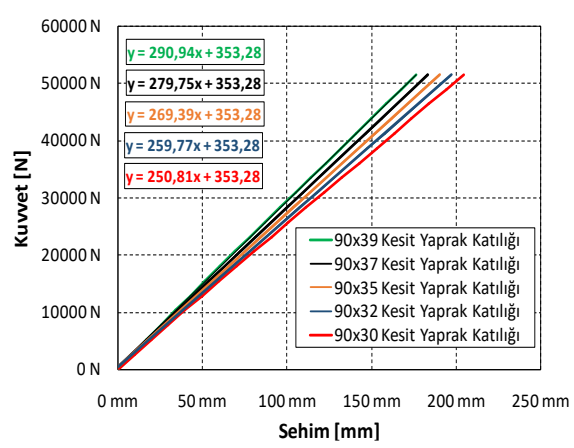

Şekil 3. Tek katlı yaprak yayın farklı kesit kalınlıklarındaki yay katılığı

Farklı kesitlerde (90x39, 90x37, 90x35, $90 \times 32$ ve $90 \times 30$ ) ve kesit ölçülerine bağlı olarak değișen parabolik yay kalınlıklarında yapılan hesaplamalar sonucunda, yay katılığı istenen aralıkta olan tek tasarım 90x39 kesit ölçüsüne sahip yay tasarımı olup bu kesit için yay katılığl $290.94 \quad \mathrm{~N} / \mathrm{mm} \quad$ olarak hesaplanmıștır. Şekil 4'te tek katlı yaprak yayın belirlenen kesit ölçüsü ve kol boylarınca değișen kalınlık değerleri yer almaktadır. 


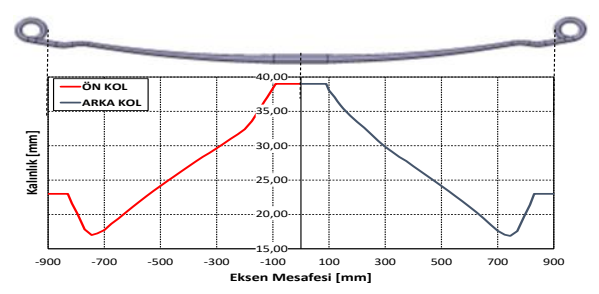

Şekil 4. Tek katlı yaprak yayın kalınlık dağılımı

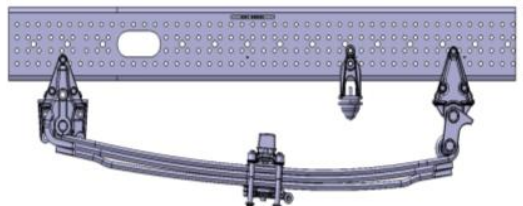

a)
Tasarımı tamamlanan parabolik yaprak yay ile günümüzde yaygın olarak kullanılmakta olan üç katlı konvansiyonel yaprak yay tasarımının ağır taşıt şasisi üzerindeki montaj görünümü Şekil 5'te gösterilmiştir.

Şekil 5. Konvansiyonel üç katlı yaprak yay (a) ve parabolik yay (b) montajı

Yaprak yay, taşıdığı kuvvetler sebebi ile eğilme gerilmesine maruz kalan bir parçadır. Bu sebeple yaprak yayda düşük gerilmelerin oluşması için alan atalet momenti değerinin yüksek olması önemlidir. $\mathrm{Bu}$ nedenden dolayı dikdörtgen kesit profili, yaprak yay için belirlenmiştir. Tek katlı yaprak yayda belirlenen kesit ölçüsü (90x39) merkez bölgesinden alınmış kesiti Şekil 6'daki gibidir. Merkezde yer alan 17.05 mm çap ölçüsündeki delik ise, yaprak yayın aks üzerindeki pime montaj yapılabilmesi için tasarlanmıştır.

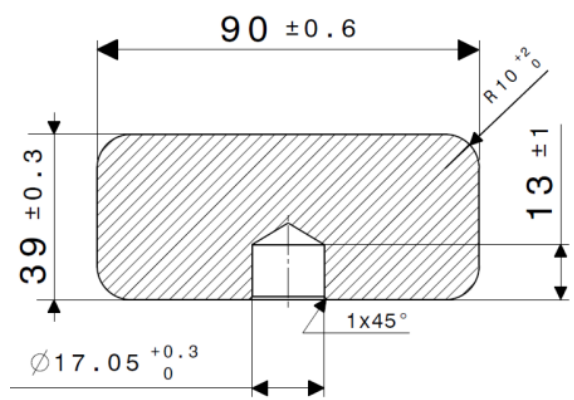

Şekil 6. Tek katlı yaprak yayın kesit ölçüsü ve profili

\section{Analiz ve Değerlendirmeler}

Yaprak yaya uygulanan kuvvetler sonucunda yaprak yayın şasi analizleri, düşey yük, frenleme yükü ve yanal yük dikkate alınarak ve Abaqus program kullanılarak yapılmıştır. Tablo 1'de belirtilen kuvvet bilgileri tek katl parabolik yaprak yayın bilgisayar destekli analizinde uygulanacak kuvvet değerlerini içermektedir. $\mathrm{Bu}$ kuvvetler taşıt tekerleğine gelebilecek sinır düșey kuvveti, maksimum yanal ve fren kuvveti değerleridir. Ayrıca bu kuvvet değerleri gerekli emniyet katsayılarını da içermektedir.

Tablo 1. Parabolik yayın maruz kalacağı maksimum kuvvetler

\begin{tabular}{|c|c|c|c|}
\hline \multirow{2}{*}{$\begin{array}{c}\text { İleri } \\
\text { Hareket }\end{array}$} & Kuvvet & \multicolumn{2}{|c|}{$\begin{array}{c}\text { Aralık Değerler } \\
{[\mathbf{k N ]}}\end{array}$} \\
\cline { 2 - 4 } & Düşey & 0 & 65 \\
\cline { 2 - 4 } & Yanal & 0 & 0 \\
\cline { 2 - 4 } Frenleme & Boyuna & 0 & 0 \\
\cline { 2 - 4 } & Düșey & 33 & 65 \\
\cline { 2 - 4 } & Yanal & 0 & 0 \\
\cline { 2 - 4 } Viraj & Boyuna & 0 & -60 \\
\hline Hareketi & Düșey & 20 & 46 \\
\cline { 2 - 4 } & Yanal & 15 & -30 \\
\cline { 2 - 4 } & Boyuna & 0 & 0 \\
\hline
\end{tabular}

Yaprak yayın ön gözü 3 eksende dönme ve öteleme hareketine karşı sabitlenmiş durumdadır ve hareketsizdir. Arka göz ise hareketli küpenin merkezi etrafında dönme hareketi yaparken, arka gözün merkezi de düșey ve boyuna eksenler etrafında öteleme hareketi yapabilir 
durumdadır. Düşey ve fren kuvveti ise, yaprak yayın merkez bölgesine uygulanacak şekilde tekerlek temas noktasından etkimektedir. Fazla yükün etkisi ile yaprak yayın belirli bir deplasman sonrasinda durmasinı sağlayan orta tampon ve arka tampon komponentleri de yine analiz programında modellenmiştir. Şekil 7'de parabolik yay elemanları ile sinır şartlarının uygulandığı bölgeler gösterilmiştir.

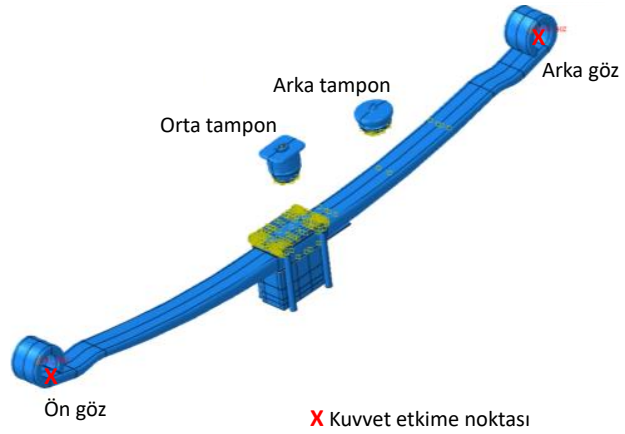

Şekil 7. Parabolik yayda kuvvet ve sinır şartlarının uygulandığı bölgeler

Hazırlanan katı modelin ç̧özüm ağı için eleman boyutu $8 \mathrm{~mm}$ seçilmiştir. Çözüm ağı atamasından sonra oluşan düğüm sayısı 9570 ve eleman sayısı 5780'dir. Eleman tipi olarak her bir elemanda 8 düğüm noktası bulunan doğrusal altı yüzlü eleman (linear hexahedral element) seçilmiştir.
Tek katlı yaprak yayın tasarımı aşamasında, ön ve arka kolda yay bağlantı gözüne yakın bölgelerde $S$ şeklinde bir form yer almaktadır. Bu formun doğru değerlerde olması, yaprak yaylı taşıtın özgül yönlendirme kabiliyetini ve yaylanma stabilitesini iyileștirmektedir. Bu form değeri özgül yönlenme testi standartlarına göre 95 $\mathrm{mm}$ ile $135 \mathrm{~mm}$ arasında alınmaktadır. Bir yaprak yay tasarımdaki $\mathrm{S}$ formunun uygun olup olmadığını tespit etmek amacı ile göbek bölgesindeki düşey yer değiştirme miktarının boyuna yöndeki yer değiştirme miktarına olan oranı irdelenir. Eğer bu yer değisstirme miktarı diğer tasarımlara nazaran daha az seviyelerde ise tasarımda belirlenen form uygundur demektir.

İlk olarak kıyaslama yapabilmek amacı ile farklı 2 yarıçap değerine sahip yaprak yay ile $\mathrm{S}$ forma sahip olmayan yaprak yayların göbek düzlüğü bölgesine düșey kuvvet uygulanmıştır. Form yarıçapları $105 \mathrm{~mm}$ ve $135 \mathrm{~mm}$ olan iki farklı yay tasarımına ait yer değiştirme değerleri formsuz durum ile kıyaslanmıştır. Şekil 8'de her üç tasarımın tümsekten geçme ve çukura düşme durumuna göre yaprak yayın boyuna yöndeki davranıșı ile form özellikleri gösterilmiștir. Tümsekten geçme durumu için $51550 \mathrm{~N}$ olan maksimum yaprak yay taşıma kuvveti (Şekil 2) ve çukura düşme durumu için ise $-33500 \mathrm{~N}$ kuvveti dikkate alınmıștır. 


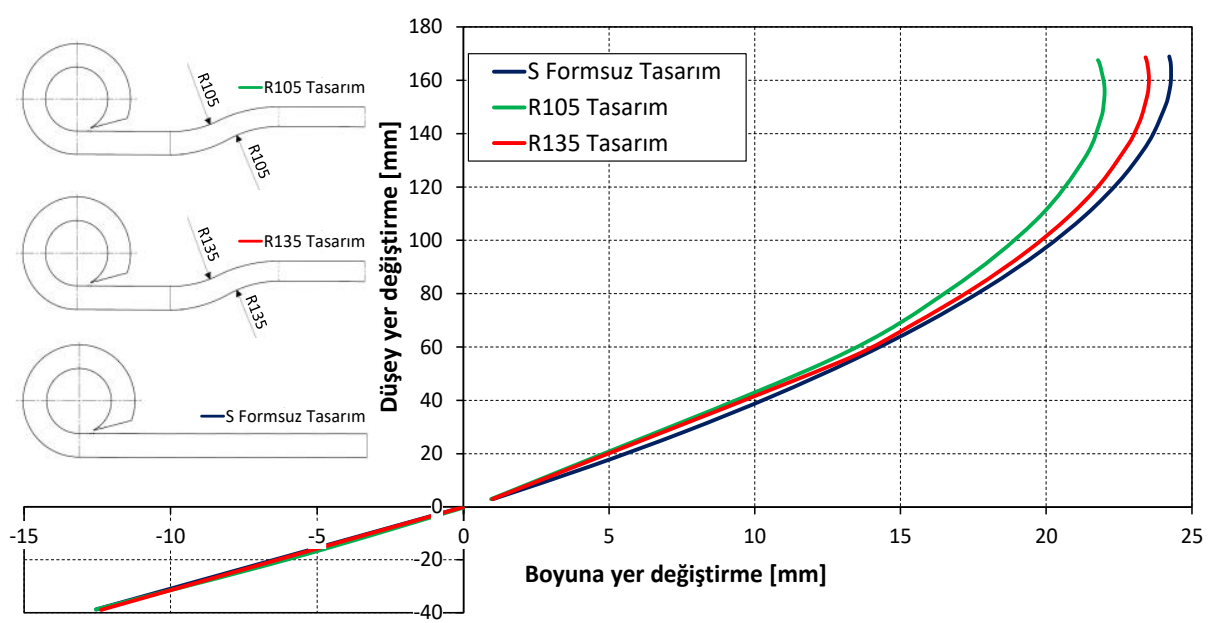

Şekil 8. Farklı formda parabolik yayların düşey harekette boyuna deplasmanları

Tablo 1'de gösterilen kuvvetlerin, belirtilen sınır şartları ile tek katlı parabolik yay katı modeline uygulanması sonucunda oluşan gerilme değerleri Șekil 9, 10 ve $11^{\prime}$ de gösterilmiştir. Gerilme sonuçları her üç yükleme durumu için de malzemenin çekme gerilmesinin altındadır.

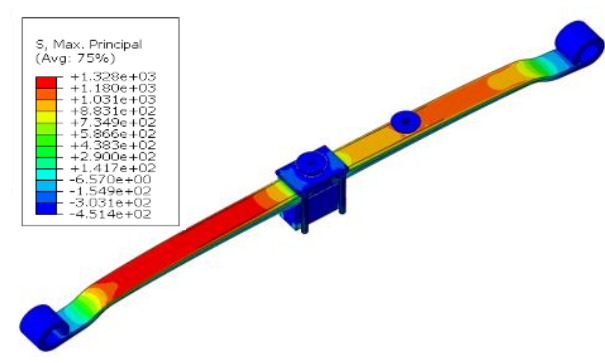

Şekil 9. Düşey yükteki gerilme dağılımı

Şekil 9'da düşey kuvvetin etkisi ile oluşan gerilmeler gösterilmektedir. Tüm gerilme sonuçlarında değerler $\mathrm{MPa}$ olarak verilmiștir. Yaprak yayın üst yüzeyinde çeki, alt yüzeyinde ise bası gerilmesi oluşmaktadır. Maksimum gerilme, yaprak yayın ön kol bölgesinde 1328 MPa değerinde oluşmaktadır.

Şekil 10'da fren kuvveti etkisi sonucunda yay üzerinde meydana gelen gerilme dağılımı gösterilmektedir. Frenleme durumunda, yayın arka kol bölgesinde yer alan tamponun yaya temas etmesi sonucunda temas yüzeylerinde maksimum gerilmeler oluşmaktadır. Oluşan maksimum gerilme değeri $1642 \mathrm{MPa}$ değerindedir.

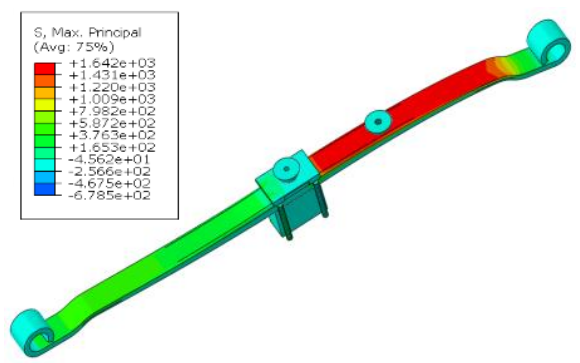

Şekil 10. Fren yükü altında gerilme dağılımı

Şekil 11'de yanal kuvvet sonucu oluşan gerilme değerleri gösterilmektedir. Yanal kuvvet altında her iki yay kolunda da (ön ve arka) yüksek gerilmeler oluşmaktadır. Maksimum gerilme arka koldaki tamponun temas noktası üzerinde $1063 \mathrm{MPa}$ değerinde oluşmaktadır. 


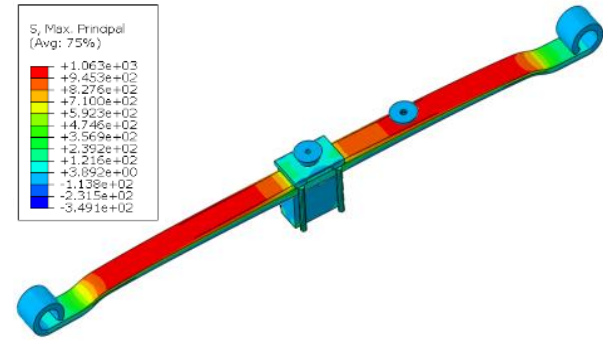

Şekil 11. Yan kuvvet altında gerilme dağılımı

Yaprak yayın tekrarlı yüklerin etkisiyle yorulması sonucu herhangi bir yerinden hasar oluşması durumu kaçınılmazdır. Yaprak yay üzerinde hasar yerinin istenen kolda olup olmadığı ile ilgili durumu gözlemlemek ve olası bir optimizasyon çalışması için çalışma bölgesine karar verebilmek adına hasar analizini gerçekleştirmek son derece önemli bir konudur.

Yaprak yay üzerinde oluşan gerilme değerlerinin ne kadarlık bir hasar etkisi yarattığını tespit edebilmek için Wöhler Eğrisi adı verilen bir gerilme-çevrim sayısı eğrisinin oluşturulması gerekir. Yaprak yayın taşıyabildiği gerilme değerleri gereği belirli bir test numunesi ve belirli bir genlik gerilmesi değerinde yaprak yaylar test edilir. Her bir genlik gerilmesi değerinde hasarlanan yaprak yayın çevrim sayılarının aritmetik ortalamalarından geçen eğri, \% 50 güven aralığı ile oluşturulan gerilmeçevrim sayısı eğrisi "Wöhler Eğrisi" olarak adlandırılır.

Tek katlı parabolik yaprak yayda oluşturulacak Wöhler Eğrisi için gerilme değerlerinin belirtildiği yorulma testi dataları Tablo 2'de gösterilmiştir.

Tablo 2. Yorulma testi dataları

$\begin{array}{ccc}\begin{array}{c}\text { Test } \\ \text { Numune } \\ \text { Adedi }\end{array} & \begin{array}{c}\text { Ortalama } \\ \text { Gerilme } \\ \text { [MPa] }\end{array} & \begin{array}{c}\text { Genlik } \\ \text { Gerilme } \\ \text { [MPa] }\end{array} \\ 5 & 700 & 650 \\ 5 & 700 & 600 \\ 5 & 700 & 550\end{array}$

Gerinim ölçer yardımı ile yaprak yay üzerinden ölçülen gerilme ile 15 adet numunenin oluşturduğu gerilme-çevrim sayısı eğrisi (Wöhler Eğrisi) Şekil 12'de verilmiştir.

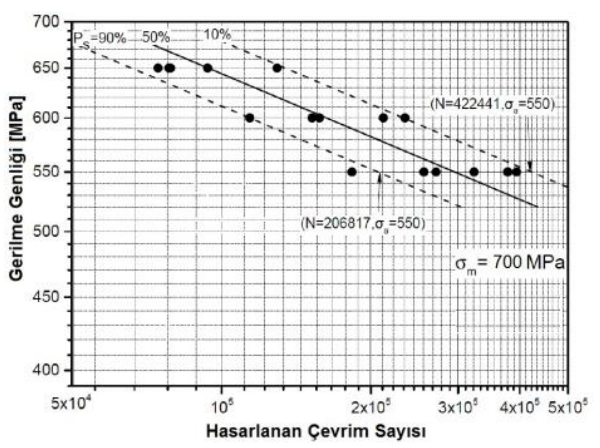

Şekil 12. Wöhler eğrisi

Hasar miktarının hesaplanmasında Miner Kuralı adı verilen bir formülün kullanımı ile hasar değeri tespiti gerçekleştirilebilir. Bu kuralın, aşağıda belirtilen formül gereği hasar değerinin toplamının yani $\mathrm{C}$ değerinin 1'e eşit olması durumunda hasar gerçekleşir şeklinde bir yaklaşımı söz konusudur. Yaprak yay tasarımlarında da bu formüldeki hesaba göre $\mathrm{C}<1$ şeklindeki tüm sonuçların hasar açısından güvenli olduğu nitelendirilir.

$$
\mathrm{C}=\sum_{\mathrm{i}=1}^{\mathrm{n}}\left(\frac{b_{i}}{N_{i}}\right)
$$

burada, $\mathrm{N}$ harfi ile belirtilen denklem girdisi düșey, fren veya yanal kuvvetin etkisi ile oluşan gerilme değerinin Wöhler eğrisinde karşılık bulduğu hasarlanan çevrim sayısını temsil ederken, b harfi ile belirtilen denklem girdisi ise her bir gerilmeyi oluşturan düşey, fren veya yanal kuvvetinin kaç defa tekrarlanacağını gösteren çevrim sayısıdir. 
Tek katlı parabolik yaprak yayın yorulma testi için belirlenen kuvvet tekrar sayıları da göz önünde bulundurularak $\mathrm{n}$ değerinin 1 'den başlayıp -800 ve +800 değerlerine kadar merkezden her $1 \mathrm{~mm}$ 'lik mesafelerde ön ve arka kolda oluşan hasar değerleri sonuçları aşağıdaki formülden çıkarılabilmektedir.
$\mathrm{A}_{n}=\sum_{\mathrm{i}=1}^{\mathrm{n}}\left(\frac{1250}{N_{\text {Dissüs }}}+\frac{130}{N_{\text {Fren }}}+\frac{128}{N_{\text {Yanal }}}\right)$

Şekil 13'de tek katlı parabolik yaprak yay için tüm kuvvetlerin etkisi göz önünde bulundurularak hesaplanan \% 90 güven aralığındaki toplam hasar analizi dağılımı gösterilmiștir.

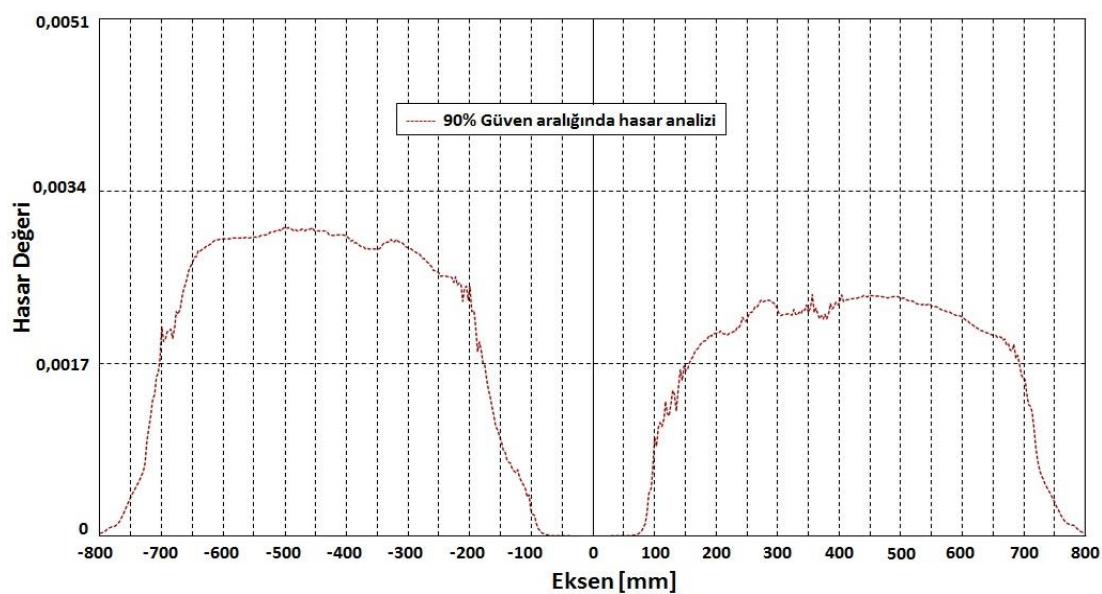

Şekil 13. Tek katlı parabolik yaprak yayın hasar analizi dağılımı

Toplam hasar dağılımı grafiğini yorumlamak gerekir ise, tek katlı parabolik yaprak yayda fren, düşey ve yanal kuvvetlerin etkisi ile oluşacak gerilmeler sonucunda hasarlanmalar \% 90 olasılıkla ön koldan $-400 \mathrm{~mm}$ ile -500 $\mathrm{mm}$ mesafe aralığında oluşacaktır. Yaprak yayın arka kolundaki toplam hasar miktarı değeri, ön kola göre daha düşük seviyelerde olması sebebi ile arka kolda hasar oluşma ihtimali ön kola göre nispeten düşüktür.

\section{Sonuçlar}

$\mathrm{Bu}$ çalışma kapsamında ağır ticari araçların ön akslarında çok katlı konvansiyonel yaprak yaylar yerine tek katlı parabolik yaprak yayların doğru ve uygun tasarım ile kullanılabileceği tespit edilmiştir.

Farklı kesit yaprak yaylar üzerinden yapılan yay katılı̆̆ analizleri neticesinde belirlenen 90x39 kesit yaprak yayın ön ve arka kolları boyunca parabolik kalınlıklar belirlenmiştir. Ön kol ve tam boy eksen ölçüleri, S şeklinde formun ölçüsü, ön ve arka göz iç çap ölçüleri, göbek düzlügü ölçüsü, serbest yay yüksekliği, yaprak yay malzemesi gibi diğer önemli parametrelerin de belirlenmesi yani tasarımın tamamlanması sonrasında düşey ve fren kuvvetlerinin etkisi ile yapılan gerilme analizlerinde seçilen tasarım diğer kesit tasarımlara göre daha düşük gerilme değerlerine sahip olduğu gözlemlenmiștir.

Analiz sonrasinda oluşan gerilme değerleri ve Wöhler Eğrisi yardımı ile yaprak yayın ön ve arka kolu boyunca her bir noktasında oluşacak toplam hasar miktarı analiz edilmiştir. Bu analiz neticesinde yorulma testinin oluşturduğu sınır hasar değerinin 
altında kalındığı, diğer bir deyişle tasarımın doğru olduğu tespit edilmiştir.

Çok katlı konvansiyonel yaprak yaydan tek katlı parabolik yaprak yaya geçilmesindeki avantajlardan ilki yaprak yay ağırlığının azalacak olmasıdır. 1 adet yaprak yayda $31.35 \mathrm{~kg}$ değerinde bir azalma söz konusudur. Ön aksta 2 adet yaprak yayın kullanıldığı dikkate alınır ise toplamda $62.7 \mathrm{~kg}$ 'lık bir ağırlık azalması meydana gelecektir. Diğer bir avantaj ise tek katlı parabolik yaprak yayın üzerindeki gerilme değerlerinde gerçekleşen iyileşmedir. Çok katlı konvansiyonel yaprak yayın gerilme değerlerine göre minimum 10 $\mathrm{MPa}$ ve maksimum $95 \mathrm{MPa}$ bir iyileşme gerçekleşmiştir.

Tek katlı parabolik yaprak yaya geçilmesindeki dezavantajlardan ilki ise çok katlı yaprak yaydaki gibi destek katlarının olmayışıdır. Yaprak yayda destek katın olmaması durumunda gerilme değerlerinin katlara bölüşmemesi, yani tüm gerilme değerinin sadece bir kat üzerinde oluşması durumu ortaya çıkar. Diğer bir dezavantaj ise yük altında tek katlı yaprak yay kuvveti sönümlemekte zorlanır. Çok katlı yaprak yayda ise bu durum katların birbirine sürtünmesi ile gerçekleşir.

\section{Teșekkür}

Çalışmaya katkılarından dolayı yazarlar, Olgun Çelik A.Ş. firmasına teşekkür eder.

\section{Kaynakça}

[1] Best, C., Hamon, C., and Mezzatesta, G., (2002). "Basic Utility Vehicle Suspension Design" The University of Texas, Austin, Fall.

[2] Bodur, F. N. (2008). "Taşıt süspansiyon sistemlerinin bulanık mantıklı kayan tipli kontrolü"
Doktora tezi, Sakarya Üniversitesi Fen Bilimleri Enstitüsü, Sakarya.

[3] Craig, K. (b.t). "Automotive Suspension Systems" Motivation for the Study of Mechanical System Physical \& Mathematical Modeling, Rensselaer Polytechnic Institute.

[4] DIN EN 10092-1, (2004). "Hot rolled spring steel flat bars".

[5] Düven, E. (2007). "Taşıtlar için aktif süspansiyon sistemlerinin geliştirilmesi" Doktora tezi, Uludağ Üniversitesi Fen Bilimleri Enstitüsü, Bursa.

[6] Fischer, G., Streicher, M., Grubisic, V. (1998). "Durability Approval of Leaf Springs Under Operational Loading" SAE Paper 982839, Indianapolis, USA.

[7] Gillespie, T.D. (1992). "Fundamentals of Vehicle Dynamics", SAE, USA.

[8] Grubisic, V. (1994). "Determination of load spectra for design and testing” Int. J. Veh. Des. 15 8-26.

[9] Karaçay, T. (2001). “Taşıt Sürüş Karakteristiğinin Durağan Olmayan İstatistiksel Analizi".

[10] Karditsas, S., Savaidis, G., Malikoutsakis, M. (2015). "Advanced leaf spring design and analysis with respect to vehicle kinematics and durability" Int. J. Struct. Integr. 6 243-258.

[11] Karditsas, S., Savaidis, G., Mihailidis, A., Savaidis, A., Fragoudakis, R. (2014). "Leaf springs - design, calculation and testing requirements" in: Proc. 35th International Symposium on Mechanics and Materials, Rhodos, Greece.

[12] Kuralay, N. S. (2008a). "Motorlu Taşıtlar" İzmir: TMMOB Makine Mühendisleri Odası. 
[13] Kuralay, N. S. (2008b). "Motorlu Taşitlar" İzmir: TMMOB Makine Mühendisleri Odası.

[14] Mansfield, N.J., Griffin, M.J. (2000). "Difference Thresholds For Automobile Seat Vibration, Applied Ergonomics" 31, 255-261.

[15] Omar, M. A., Shabana, A. A., Mikkola, A., Loh, W., Basch, R. (2004). "Multibody System Modeling of Leaf Springs" Journal of Vibration and Control, Sage Publications.

[16] Prasad, N., Tewari, V.K., Yadav, R. (1995). "Tractor Ride Vibration-A Review" Journal of Terramechanics, 32, 4, 205-219.

[17] Savaidis, G., Malikoutsakis, M., Savaidis, A., (2013). "FE simulation of vehicle leaf spring behavior under driving maneuvers" Int. J. Struct. Integr. 4 (1) 23-32.

[18] Schütz, W. (1967). "Über eine Beziehung zwischen der Lebensdauer bei konstanter und veränderlicher

Beanspruchungsamplitude und ihre Anwendbarkeit auf die Bemessung von Flugzeugbauteilen, Zeitschrift für Flugwissenschaften" 15 407-419.

[19] Society of Automotive Engineers (SAE), (1990). "Spring Design Manual".

[20] T.C. MILLİ EĞiTiM BAKANLIĞI (MEB), (2005). "Süspansiyon Sistemleri" MEGEP (Mesleki Eğitim ve Öğretim Sistemini Güçlendirme Projesi), Ankara.

[21] TS EN 10089 (2005). "Su verilmiş ve temperlenmiş yaylar için sıcak haddelenmiş çelikler - Teknik teslim şartları".

[22] Topbaş, M. A. (1998). "Çelik ve Isıl İşlem El Kitabı" Ekim Ofset ve Mücellithanesi, İstanbul.
[23] Warmgeformte F. (1987). "Konstruktion und Fertigung" Frankfurt.

